Article

\title{
Unauthorised Domestic Water Consumption in the City of Alicante (Spain): A Consideration of Its Causes and Urban Distribution (2005-2017)
}

\author{
Álvaro-Francisco Morote ${ }^{1, *(1)}$ and María Hernández-Hernández 2 (i) \\ 1 Department of Geography, University of Santiago de Compostela, 15782 Santiago de Compostela, Spain \\ 2 Interuniversity Institute of Geography, University of Alicante, 03080 Alicante, Spain; maria.hernandez@ua.es \\ * Correspondence: alvaro.morote@usc.es
}

Received: 15 May 2018; Accepted: 24 June 2018; Published: 26 June 2018

\begin{abstract}
Since 2014 and 2015 numerous projections and macroeconomic indicators have shown sustained growth, allowing governments to affirm that the economic crisis has been overcome. In Spain, the onset of the crisis and the bursting of the real estate bubble (2008) have caused a profound impression on the country and society in recent years. The aim of the study is to analyse the evolution and the determining factors of unauthorised domestic water consumption and its geographic distribution in the city of Alicante (south-east Spain). Methodologically, data have been examined regarding this topic in the city of Alicante for the period 2005-2017 and according to their location and the type of residential property (compact or dispersed). In conclusion, it should be indicated that in Alicante unauthorised consumption is recorded in all social classes and neighbourhoods, especially in the properties of the North District of the city (a lower economic income neighbourhood) but also in those ones that are home to the better-off social classes who reside in detached houses. In the latter, residents commit unauthorised consumption to reduce the high levels of water consumption, aggravated by the current drought (the need to provide greater volumes of water for outdoor uses) and by the increase in the price of water over the last decade. Besides, since the implementation of the Remote Meter Reading Plan in 2011 and the increase of the surveillance of the employers of the water company, the detection of the unauthorised water consumption has increased.
\end{abstract}

Keywords: unauthorised consumption; water; consumption; domestic; Alicante

\section{Introduction}

Losses and unauthorised water consumption are an important problem for the water sector $[1,2]$. Water loss is the water that is produced but not sold to customers or used by or via the utility [3]. According to Farley et al. [4], the global average level of water losses is $35 \%$ of produced water which accounts for 48.6 Billion Cubic Meter (BCM) per year. The IWA Task Forces on Performance Indicators [5] and water losses have recently produced an International "best practice" standard for defining and calculating components of water balance and selecting the most appropriate Performance Indicators for different components of Non-Revenue Water (NRW) and Water Losses [2].

Water losses have two main components: Real and apparent losses [6]. The first ones also called physical losses, refer to the water that leaks out of pipes [1]. The apparent losses are defined as result of a trade balance because is not physically lost but used by a customer and not paid for. The apparent losses include illegal water use, customer meter under-registration and data handling or billing errors. The difference between NRW and water losses is the amount of authorized consumption that is used legally but not billed or paid for (unbilled authorized consumption) [3]. 
Losses affect supply sustainability and have an impact on the environment due to the increase in the volume extracted [7-9]. In relation with meter tampering is a significant obstacle for utilities (both power and water distribution) to address because it represents an important loss of income [10,11]. In the study of Lambert [7] it is reflected that unauthorised water consumption occurs to a greater or lesser extent in most systems worldwide. For example, in England \& Wales that unauthorised consumption estimated is $0.36 \%$ of System Input Volume. The Australian, Moroccan and USA National Reports specifically mention this component of Apparent Losses, which is generally associated with misuse of Fire Hydrants and Fire Service connections and illegal connections [7]. Checking for possible illegal connections commences with identification of customers with unusually low consumption. In the USA, the M36 Audit procedure recommends that Unauthorised Consumption is best dealt with through 'good billing procedures' [12].

Water companies are struggling to locate points where unauthorised consumption and leaks occur $[11,13]$. Several research works propose methods for predicting demands and classifying them based on different approaches, including statistical models and machine learning models [14-18]. For example, Pietrucha-Urbanik [19] presents the differentiation in the level of water supply infrastructure in the Polish provinces and they predict the future infrastructure operation using multidimensional comparative analysis. Also, important issue is future prediction concerning failure state [20,21]. Pietrucha-Urbanik and Tchórzewska-Cieślak [22] explain that in order to understand the current situation of water supply infrastructure it is necessary to perform periodic analyses of water supply network failure.

When analysing unauthorised water consumption, it should be taken into account that, this depends on its detection and whether measures for detection are taken [7]. Many efforts have been made aiming to promote a better management of unauthorised consumption detection. This is one of the efforts to promote a better management of water as the illegal connections are usually held precariously, thus causing leaks [23]. The main method of detection is inspection with the use of acoustic equipment, a slow and costly method, which requires the entire length of the pipes to be searched for the leakage point [24]. In most cases, the selection of sites for inspection is performed at random. Even when there is an attempt to direct the inspection, the selection of the areas is carried out empirically, making it difficult to locate the unauthorised consumption $[25,26]$.

In Spain, one of the technologies most widely developed recently in order to detect unauthorised consumption is remote meter reading [27], a technology with which countries such as Australia have considerable experience [28-30]. Remote technologies together with network subdivisions are the best examples of the new smart models of water supply management designed to improve efficiencies in distribution, consumption and billing and also show new business models for companies searching to improve their economic and financial performance in the contexts of declining water use. In the past few years and after the widespread introduction of the smart city concept in Spain [31], smart water metering has gained central attention as a critical mediator to improve urban water supply planning in the 21st century [26,32].

In recent years water management has been a recurrent object of study as a consequence of the increased pressure to which this resource is subjected [26]. International scientific literature abounds with publications that analyse the factors that have a bearing on increased demand, the possible effects deriving from climate change, changes in regulations, and so forth [33]. However, few studies have analysed unauthorised consumption, the causes that generate it or its regional implications [1,23,32,34-36].

Enhancing knowledge of this subject is fundamental in order to improve management of this resource, a factor that is especially necessary in regions with a scarcity of water resources and in the light of future climate change scenarios. In Spain and particularly in Alicante (the Mediterranean area), the region with the greatest water deficit in the country, there is an almost total absence of publications on this subject [26].

In Alicante, the political ecological process that has radically transformed the country's water environments follows the classic modernization path: From the dams and reservoirs that allowed the expansion of irrigation and hydroelectricity in the 1940s and 1950s to the inter-basin water transfers that added water flows for urban and mass tourist growth in the Mediterranean areas of the 1960s and 
1970s [25]. After this period, the most recent development is the construction of desalination plants responding to the new water demands linked to an increase in outdoor water use, associated with the real estate bubble of the 1990s and 2000s [37]. It is during this last period that the expansion of new urban environments (gardens and pools) must be placed as perhaps the most recent beacon of urban modernity in the country. However, the collapse of the real estate market from 2008 onwards and recurring climatic hazards such as droughts combine to check water-based urban growth in such a way that threatens the very fabric of urban modernity. Moreover, Alicante is a semi-arid area ( $311 \mathrm{~mm} /$ year) and one of the fastest growing regions of Southern Europe in terms of residential tourism and also an area subject to periodic water crises due to the combination of recurrent droughts and expanding agricultural, urban and tourist water demand [25].

This paper aims to contribute to increasing the knowledge regarding the causes of unauthorised domestic water consumption in the city of Alicante (2005-2017) (South-eastern Mediterranean coast), one of the Spanish cities where the development and the implementation of new water technologies is more intense [24]. This knowledge is related to the importance acquired by the improved management of this resource in recent years owing to the increase in demand associated with urban uses linked to the increase in types of development with a proliferation of outdoor elements [38], the future climate change scenarios and the technological advances introduced by water supply companies to enable them to manage this resource more efficiently [26,38]. In this sense, according to the World Bank, in 1953 Alicante became the first international example of a successful water company of mixed (public and private) capital under the name of "Aguas de Alicante". Tourist activity and particularly residential tourism, has led to a change in the urban and demographic model of towns along the European Mediterranean coastline. The city of Alicante is a clear example of this. The climatic characteristics make it one of the most arid places in Spain, the common episodes of droughts [39] and the recent decrease in water consumption [40] explain the interest in this case study. The interest and innovation of this study lie in a series of questions. First, the lack of literature that examines the factors and causes that generate and foster unauthorised water consumption from a socio-regional perspective, not only in the area studied (Alicante, south-east Spain) but also on a national and international scale $[1,10]$. Besides, it should be added that an analysis of unauthorised consumption is a good indicator of the socio-economic status of any urban area with specific socio-economic features. Lastly, the relevance of a study in which sensitive data have been used, which the supply companies are reluctant to provide. In fact, the use of real data on water consumption in Spain, unlike other countries, is not frequent, owing to the difficulty in accessing them, owing to which they are usually replaced by extrapolations and estimates based on data deriving from surveys.

Based on these premises, the aims of this study are: (1) To analyse the geographic distribution and by type of residential property of unauthorised consumption in the city of Alicante in the period 2005-2017); (2) To identify the causes that explain unauthorised consumption in Alicante; and (3) To analyse and evaluate the measures adopted by the supply company to detect and combat unauthorised consumption.

After the introduction which sets out the interest of the topic of study and the scarcity of scientific publications on this subject, a presentation is given of the methodology used, the results obtained according to the 3 aims proposed, the discussions and, finally, the conclusions.

\section{Materials and Methods}

Methodologically, an analysis has been made of data on unauthorised domestic water consumption for the 2005-2017 period in the city of Alicante, provided by the company responsible for supply in the city of Alicante. Currently, the official full name of the water supply company is "Aguas Municipalizadas de Alicante, Empresa Mixta" (Municipal Waters of Alicante, Joint Company) (AMAEM) and its ownership is divided into equal shares between the City Council of Alicante and the private company Hidraqua, Gestión Integral de Aguas de Levante S.A., a subsidiary of Aquadom (Suez Environment). Although under the supervision of the public partner, Hidraqua in Alicante 
enjoys ample autonomy in technical decision-making [24]. These data have been compared with variables relative to population and property obtained from the Population and Housing Census and the Municipal Register of Inhabitants, socio-demographic and economic data of the urban districts of the city of Alicante [41] and climate data (annual and monthly precipitation) provided by the observatory of Ciudad Jardín (Alicante, AEMET).

To achieve aim number 1, data provided by AMAEM on the number of unauthorised domestic consumption actions detected for the 2005-2017 period have been used, differentiating between urban development typologies (compact and low density) and geographic location (North District, Beach Area, Urban Core and Rural District) (Table 1). The choice of this period is determined by the following factors: (a) 2005 corresponds to the situation prior to the economic crisis; and (b) 2017 corresponds to the last year for which data are available and, with regard to macroeconomic data, the economic recovery. The analysis over time makes it possible to compare the evolution of the number of domestic unauthorised consumption actions detected prior to the beginning of the economic crisis (2008) and to see how the trend has behaved until 2017.

Table 1. Characteristics and location of the urban development typologies analysed.

\begin{tabular}{ccc}
\hline Urban Development Typology & Characteristics & Location (Urban Sectors) \\
\hline Compact & $\begin{array}{c}\text { Inexistence of outdoor elements } \\
\text { (garden and swimming pool) }\end{array}$ & $\begin{array}{l}\text { - North District } \\
\text { - "Beach" Area (urban-tourist zone) } \\
\text { - Urban Core }\end{array}$ \\
\hline Low density (houses) & $\begin{array}{c}\text { Presence of outdoor elements } \\
\text { (garden and single-family } \\
\text { swimming pool) }\end{array}$ & $\begin{array}{l}\text { - "Beach" Area (urban-tourist zone) } \\
\text { - Rural District }\end{array}$ \\
\hline
\end{tabular}

Subsequently, to achieve aims 2 and 3 the technicians of AMAEM (customer and remote metering area) were interviewed in January 2018. The aim was to ascertain, from the technical point of view, the current status of unauthorised consumption in the city of Alicante, to look into the causes that may generate it and to identify the measures adopted by the company for its detection. The semi-structured interview, performed during the month of January 2018, was formulated around the following items: (a) Impact of the economic crisis; (b) Importance of economic income; (c) Importance of urban development typology (compact model and low density); (d) Impact of the current drought (2015-2018); (e) Increase in the price of water in the last years; (f) Impact of the improvement and implementation of technology (Remote Meter Reading Plan 2011) and actions for the detection of unauthorised consumption; and (g) General balance and current status of unauthorised consumption in the city of Alicante and future projections.

Finally, these interviews were complemented with information on monthly unauthorised consumption data (year 2017; last data available) to determine the possible influence of the climatic conditions paying particular attention to the summer period (characterized by its dryness) when water consumption for domestic uses increases. To achieve this, climatic data (precipitations) from the observatory of Ciudad Jardín (Alicante, AEMET) were consulted and were contrasted with consumption and unauthorised consumption. Secondly, the evolution of the price of water $\left(€ / \mathrm{m}^{3}\right)$ has also been subject to analysis for the 2005-2017 period, the number of domestic customers in order to compare the ratio of unauthorised consumption detected per customer (properties connected to the network) (2005-2017), water supply by urban districts (2005-2017) and the approximate average amount $(€)$ and volume obtained illegally $\left(\mathrm{m}^{3}\right)$ per annum per urban sector and type of property (2017).

\section{Results}

\subsection{Geographic and Urban Distribution of Unauthorised Domestic Water Consumption in the City of Alicante}

Based on socio-economic characteristics [41] and urban development typologies of the four main urban sectors have been differentiated in the city of Alicante (Table 2 and Figure 1): 
(a) The urban district known as "North District" (compact urban development type). This sector includes the neighbourhoods with the lowest economic income per household in Alicante $(€ 12,756 /$ year), the largest percentage of families with difficulties to paying monthly bills (30.9\%), the lowest percentage of population with university studies (9.1\%) and highest rates of inhabitants with no studies $(12.7 \%)$.

(b) The "Beach Area," formed by neighbourhoods characterized by the predominance of urban-tourism activities, although in the last decade its significance has lessened with the appearance of new urban developments for main residential properties which are occupied by young couples with children, attracted by this type of urban development (terraced and detached houses). This is the sector with the highest annual average income of the city $(€ 29,158)$ and with the highest percentage of population with university studies $(50.2 \%)$.

(c) The rest of the urban districts that make up the urban core or nucleus of the city of Alicante, with a predominance of the compact urban development typology and a predominance of middle classes.

(d) The Rural District, which is located in various sectors of the municipality of Alicante with a predominance of country houses and residential complexes with detached houses.

Table 2. Main socio-economic data of the differentiated urban areas of the city of Alicante (2016).

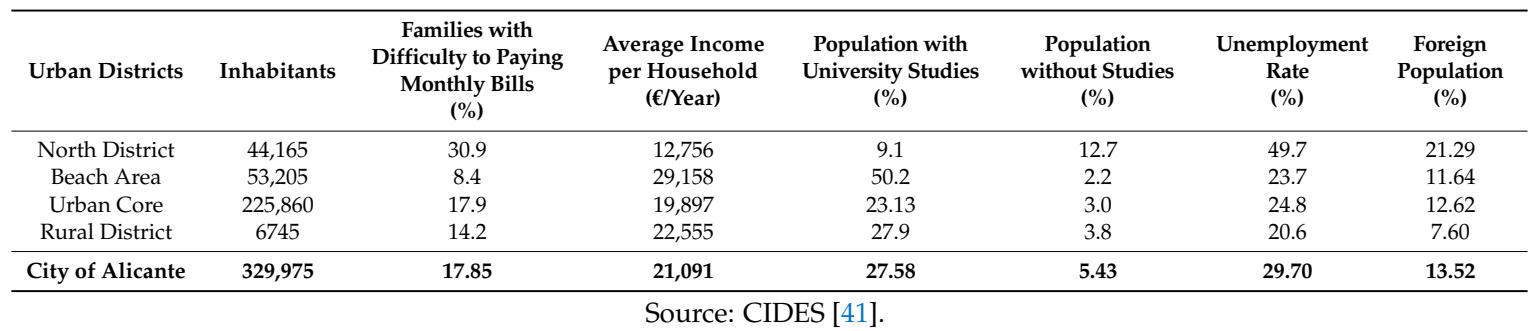

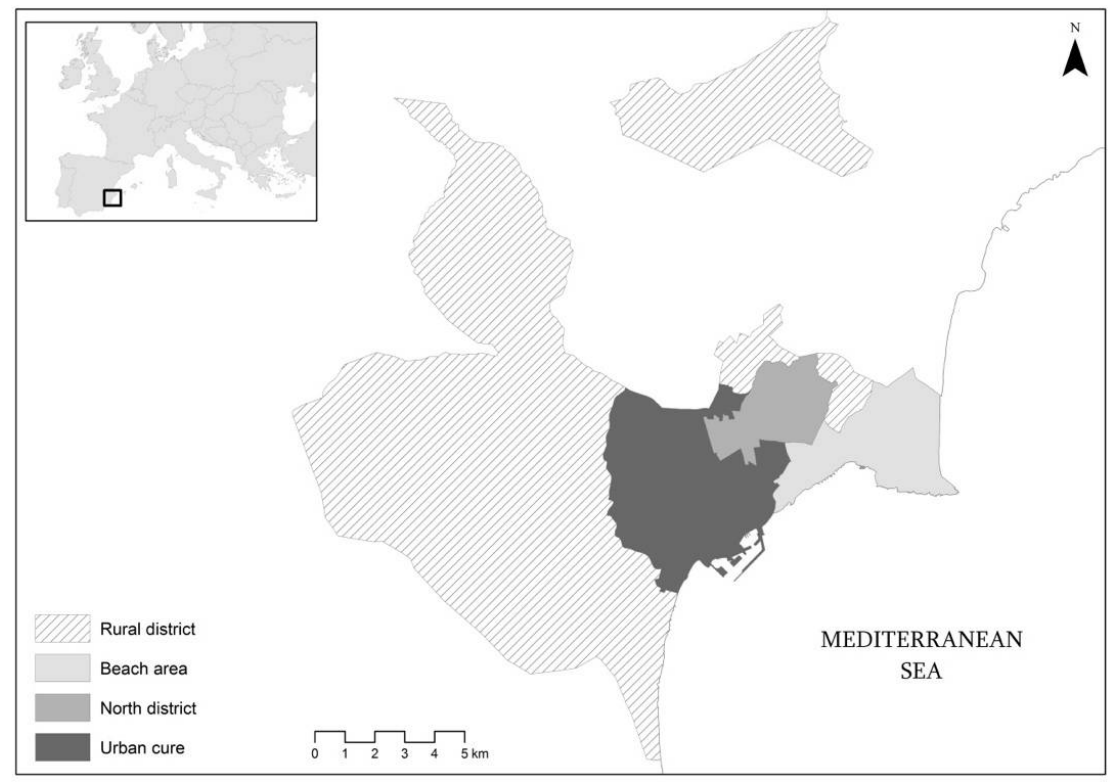

Figure 1. Study area. Own Elaboration.

In 2017, AMAEM supplied 23.23 million cubic metres of water to the city of Alicante $(329,988$ inhabitants) mostly for the domestic sector (63\%). Between 2004 and 2017 the domestic sector declined by $13.47 \%$. In the domestic sphere, water consumption per capita fell $22 \%$ between 
2004 and 2017 (from 150 down to $123 \mathrm{~L}$ / person/day) owing to multiple interrelated causes, such as more efficient water fixtures and appliances; growing consumer awareness; smaller demographic and economic growth; and also the effects of rising prices and taxes, especially among low-income groups.

In relation with the number of unauthorised domestic water consumption detected according to urban development type (compact or low-density development) between 2011 and 2014, it is apparent that there is a generally rising trend. The main reason is due to the implementation of the Remote Meter Reading Plan (2011) and the increase of the surveillance of the employers of the water company that now, the company detect more unauthorised consumption than before. Also, it is important to taking into account that nowadays, not all the city is covered by this Plan (especially, the Rural District) and moreover, new ways of unauthorised consumption in the smart meters are produced (see point 3.2). For this reason, is complex to compare the trend of unauthorised consumption between 2005 and 2017.

Since 2005, AMAEM has recorded a total of 2207 frauds for the domestic sector; the majority ( $83 \%)$ concentrated in the compact urban development model. The years for which the most frauds were recorded in this urban typology were 2013 and 2014 (with 377 and 378 frauds, respectively) which represents an increase of $1481 \%$ between 2005 and 2014. The analysis of the ratio of contracts/fraud demonstrates that in 2005, this ratio amounted to 6066 contracts/fraud (compact urban model) and 6127 contracts / fraud (low density urban model). However, in 2017, thanks to the implementation of the Remote Meter Reading Plan (2011) and the increase of the surveillance of the employers of AMAEM, the unauthorised water consumption detected has been increased (768 contracts/fraud in the compact model and 607 contracts / fraud in the low-density model). This analysis demonstrates that in the low density urban model (detached houses of the Rural District and Beach Area), unauthorised water consumption is most important in relative terms than in the compact model (Figure 2).

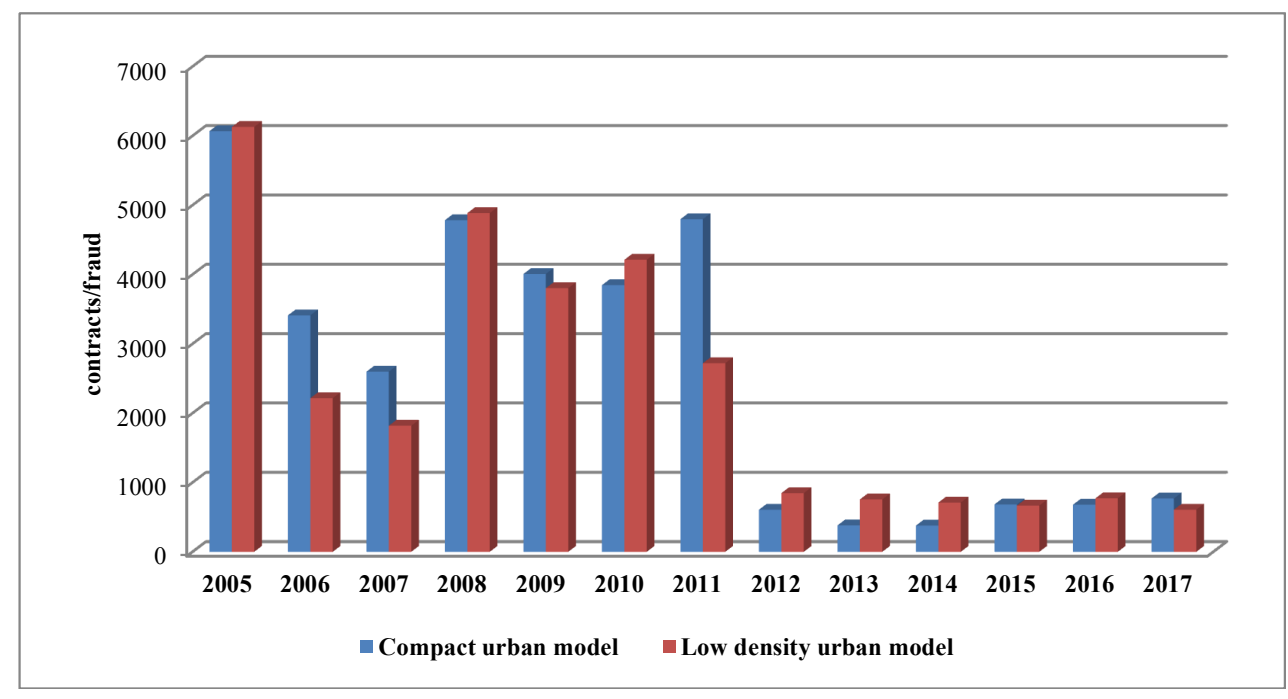

Figure 2. Evolution of the ratio contracts/fraud detected in the city of Alicante according to urban development typology (2005-2017). Source: AMAEM. Own elaboration.

In the compact model, according to geographic location (North District, Beach Area and Urban Core), it is appropriate to indicate that the majority of the unauthorised consumption detected is located in the North District (70\% for the 2005-2017 period). The year in which the most unauthorised consumption was detected was 2014 with a figure of 299 frauds (79\% of the total for that year in the compact model). The analysis of the ratio contracts/fraud demonstrates that unauthorised water consumption detected is most important in this area. For example, in 2014, this ratio amounted to 55 contracts/fraud. However, in 2014, in the Beach Area this ratio amounted to 1509 and 1616 contracts/fraud in the Urban Core (Figure 3). 


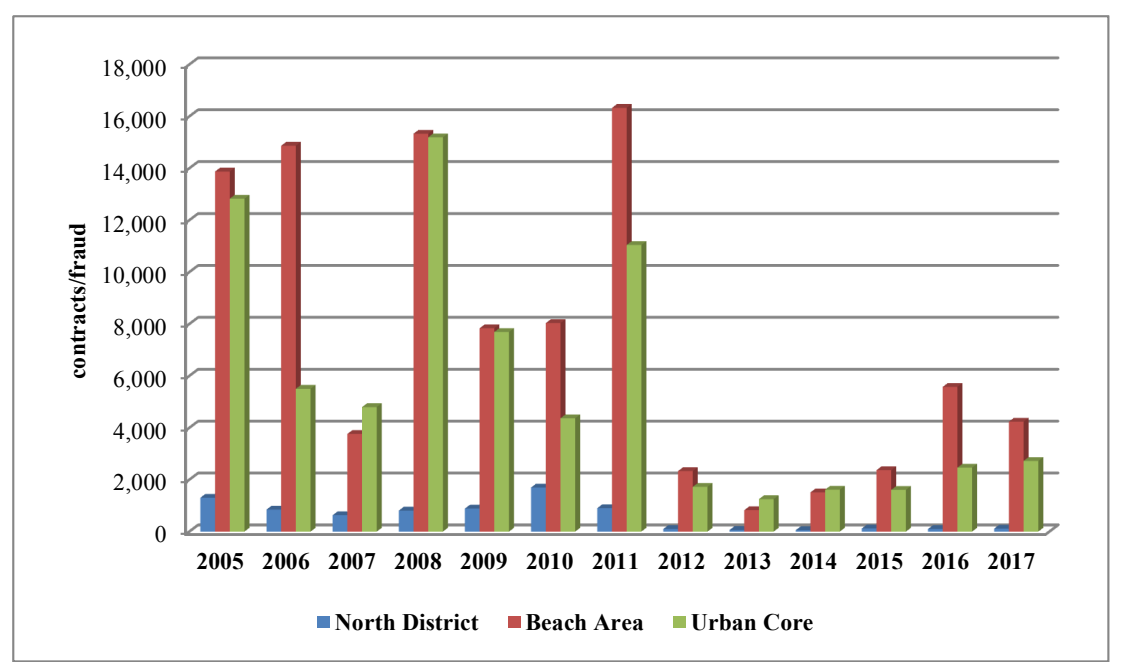

Figure 3. Evolution of the ratio of contracts/frauds detected in the compact urban model (2005-2017). Source: AMAEM. Own elaboration.

In the low density urban development model, the majority of the frauds detected have been recorded in the detached houses located in the Rural District (88\% for the 2005-2017 period). For example, in 2017, the ratio contracts/fraud amounts to 208 in this area (Figure 4). However, in the Beach Area, practically it is not detected unauthorised water consumption (6992 contracts/fraud). In the case of the Rural District, it should be noted that the downward trend since 2014 is not as evident as the case of the compact model. The reduction of precipitation that has affected this part of Spain since 2014, which has forced residents have to provide an important and additional volume of water for watering the garden, orchard, filling the pool, and so forth, and because the Remote Meter Reading Plan is not implemented in this area, are the main reasons that explains this trend. The average rainfall in Alicante is $311 \mathrm{~mm} /$ year but this amount was significantly reduced: $140 \mathrm{~mm}$ in 2014, $137 \mathrm{~mm}$ in 2015 and $212 \mathrm{~mm}$ in 2016. Besides the drought, the price of water ( $€ 2.23 / \mathrm{m}^{3}$, one of the highest in Spain) is another factor that explains that the number of unauthorised water consumption in this area of the city (Rural District) is high and, particularly, constant. In addition, the lack of cheaper water as the reclaimed water $\left(€ 0.32 / \mathrm{m}^{3}\right)$ enhances the likelihood of fraud. It uses in the Beach Area explains the lower number of unauthorised consumption.

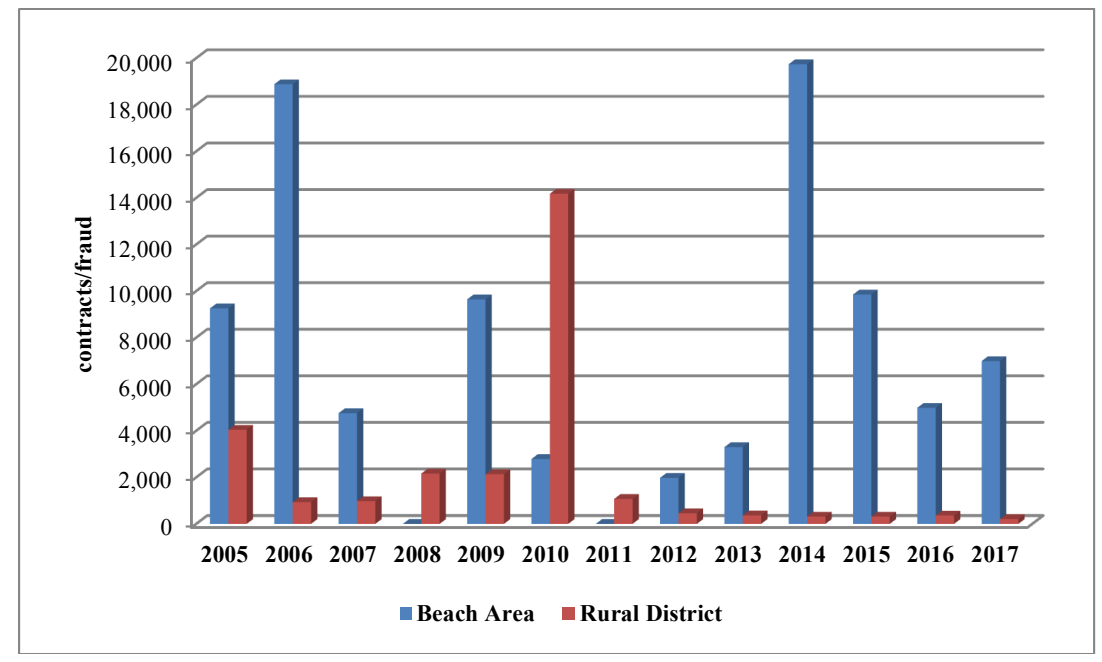

Figure 4. Evolution of the ratio contracts/frauds detected in the low density urban model (2005-2017). Source: AMAEM. Own elaboration. In 2008 and 2011 AMAEM did not detected unauthorised consumption in the Beach Area. 


\subsection{Causes and Distribution of Unauthorised Domestic Water Consumption: An Amalgam of Multiple and Interrelated Causes}

Firstly, it is important taking into account that in Alicante, two types of unauthorised water consumption have been identified: Illegal connections to the water network (especially in the detached houses of the Rural District) and practices to handle the meter tempering (in all urban typologies and districts) with the installation of a magneton. Besides, according to the comments of the technicians of AMAEM, they are detecting new ways of handling the meter tempering that affect the reading of the new appliances installed with the Remote Meter Reading Plan (2011).

With the information provided by AMAEM and the analysis conducted, it has made possible to identify the following factors that explain the unauthorised consumption in the city of Alicante: (a) Urban development type; (b) Economic income; (c) Economic crisis; (d) Increase in the price of water in recent years; (e) Current drought; (f) Reuse of treated water; and (g) Remote Meter Reading Plan (2011) and the surveillance of the employers of the water company (Figure 5). Furthermore, it should be indicated that, on occasions, interrelated factors are involved, as is the case of the economic crisis or the increase in the price of water which may have had a more noticeable impact on social classes with less purchasing power.

Urban development typology and unauthorised consumption are correlated. In this sense, it has been noticed that the great majority ( $83 \%$ of frauds detected) are recorded in the compact model. This high concentration is repeated in one of the districts (North District). This last is the setting for $70 \%$ of total incidents in this type. This feature is accentuated since this sector alone concentrates $59 \%$ of the total of the unauthorised consumption detected of the whole city of Alicante. Besides, the level of fraud is the highest in this area of the city (115 contracts/fraud in 2017) in compare with the detached houses of the Beach Area (6992 contracts / fraud).

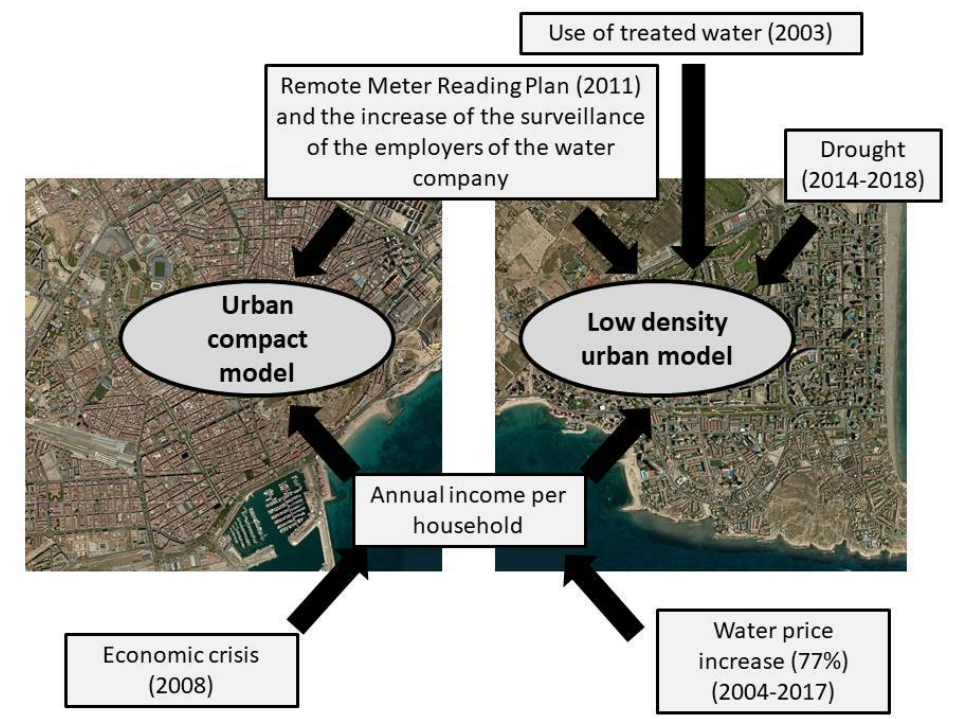

Figure 5. Relationship of factors that influence unauthorised domestic water consumption in the city of Alicante. Own elaboration.

In line with these data, income level appears to be a factor that would explain the distribution of frauds in Alicante, both when differentiating between types and with regard to their concentration in one sector of the compact type (North District). The interrelation of a series of factors of an economic nature (income per capita, economic crisis and increase in the price of water) explains this marked concentration (see Table 2). In the North District, the economic crisis has further affected the economic capacity of the resident population, that with the lowest income level of the city (40\% below the average income). The noticeable increase in the number of unauthorised consumption recorded as of 2011 can be explained by: (1) The implementation of the Remote Meter Reading Plan (2011) and 
the increase of the surveillance of the employers of AMAEM; (2) The intensity and, especially, by the duration of the crisis which has led to numerous families exhausting their savings and social benefits; and (3) This reduced economic capacity has been accentuated by the increase in the price of water which, between 2004-2013, increased by 77\% [24], coinciding with part of the period when the intensity of the crisis was greatest. For example, for a consumption of $30 \mathrm{~m}^{3}$ /quarter the price paid rose from $€ 37.75$ to $€ 67.06$; a cost that had been increased until 2017 (92.79\%) (mean price of $€ 2.23 / \mathrm{m}^{3}$ ). In the case of the lowest social classes who obtain water illegally in the North District, it is appropriate to indicate that, as was stated during the interview with the technicians of AMAEM, in the majority of cases their debt is forgiven and they need only pay $€ 140$ for the concept of installation of the new meter (since the old one is unusable) and the labour for the installation. This is because AMAEM "is not interested in these families running up debts with the company and because they know they are not going to pay." Furthermore, it should be pointed out that since 2012 AMAEM has applied an income-based discount (reduced water rate), which is situated at an average of $€ 200,000 /$ year. This has allowed families at risk of social vulnerability (for example, with all the members unemployed) to see a notable decrease in the expense of the water bill or even a refund of the total amount.

The interrelation between incidents of unauthorised consumption, socio-demographic characteristics (total population) and data relating to water supply (volume served and number of contracts) makes it possible to incorporate new qualitative and quantitative elements in the analysis of this process. As said before, in the relationship between domestic contracts and unauthorised domestic water consumption, the lowest values, that is, the highest level of fraud, are recorded in the North District (115 contracts per fraud), which would corroborate the dynamics described. However, in second place is the Rural District (detached houses) with 208 contracts per fraud, which situates it closer in percentage terms to the North District than to the Beach Area. In the Beach Area (low density urban model), to detect a fraud, 6992 domestic contracts are required, the highest of the city, which would corroborate the relationship between higher level of income, lower level of fraud. It is in this sector where the highest average income per household is recorded (around $€ 29,000 /$ year).

The dynamics described in the correlation between the numbers of contracts/fraud are repeated in that of the number of inhabitants/fraud for the year 2016. In this later ratio, it is in the Rural District (178 inhabitants / fraud) and in the North District (269 inhabitants/fraud) where the highest level of frauds per inhabitant is recorded of the whole city in compare to the Beach Area in the low urban density model (7853 inhabitants/fraud) (Table 3). In the correlation between water supplied and unauthorised consumption, the highest-level values again correspond to the North District and the Rural District, which in 2017, one fraud is recorded every $8873 \mathrm{~m}^{3}$ (Figure 6) and $17,764 \mathrm{~m}^{3}$ (Figure 7), respectively. In addition to the income factor, which would explain the volume of unauthorised consumption in the North District, other factors are incorporated in the Rural District such as the volume of water consumed by outdoor elements (gardens and swimming pools) which considerably increase consumptions (more than 1000 L/property/day) [25]. The higher demands and their concentration in the summer period associated with the requirements for outdoor uses (filling of swimming pools and watering the gardens) will determine that a concurrent factor such as drought has an impact on the number of unauthorised consumption in the Rural District.

Table 3. Unauthorised domestic water consumption according to the different socio-demographic and economic characteristics of the city of Alicante (2017).

\begin{tabular}{ccccc}
\hline Urban typology & Urban District & $\begin{array}{c}\text { No. Domestic } \\
\text { Contracts/Fraud }\end{array}$ & No. Inhab./Fraud & $\begin{array}{c}\text { Domestic Water } \\
\left.\text { Consumption } \mathbf{( m}^{\mathbf{3}}\right) / \text { Fraud }\end{array}$ \\
\hline \multirow{2}{*}{ Urban compact } & North District & 115 & 269 & 8873 \\
model & Beach Area & 4237 & 7264 & 326,923 \\
& Urban Core & 2723 & 5019 & 201,377 \\
\hline \multirow{2}{*}{ Low density model } & Beach Area & 6992 & 7853 & 823,642 \\
& Rural District & 208 & 178 & 17,764 \\
\hline
\end{tabular}

Source: AMAEM; Council of Alicante. Own elaboration. Note: For the case of the ratio Inhab./Fraud data of 2016 have been used. 


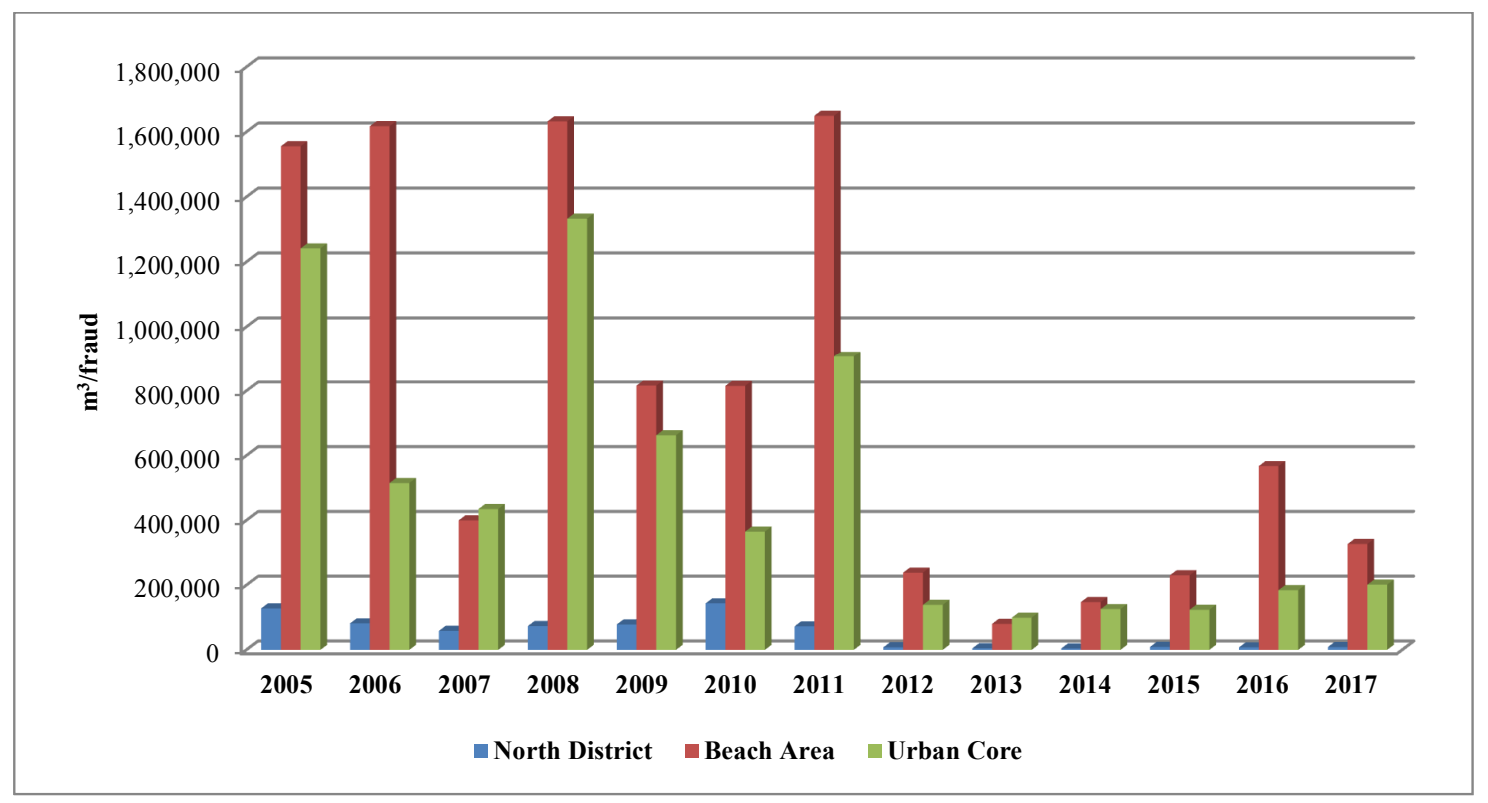

Figure 6. Evolution of the ratio of domestic water supply $\left(\mathrm{m}^{3}\right) /$ frauds detected in the compact urban model (2005-2017). Source: AMAEM. Own elaboration.

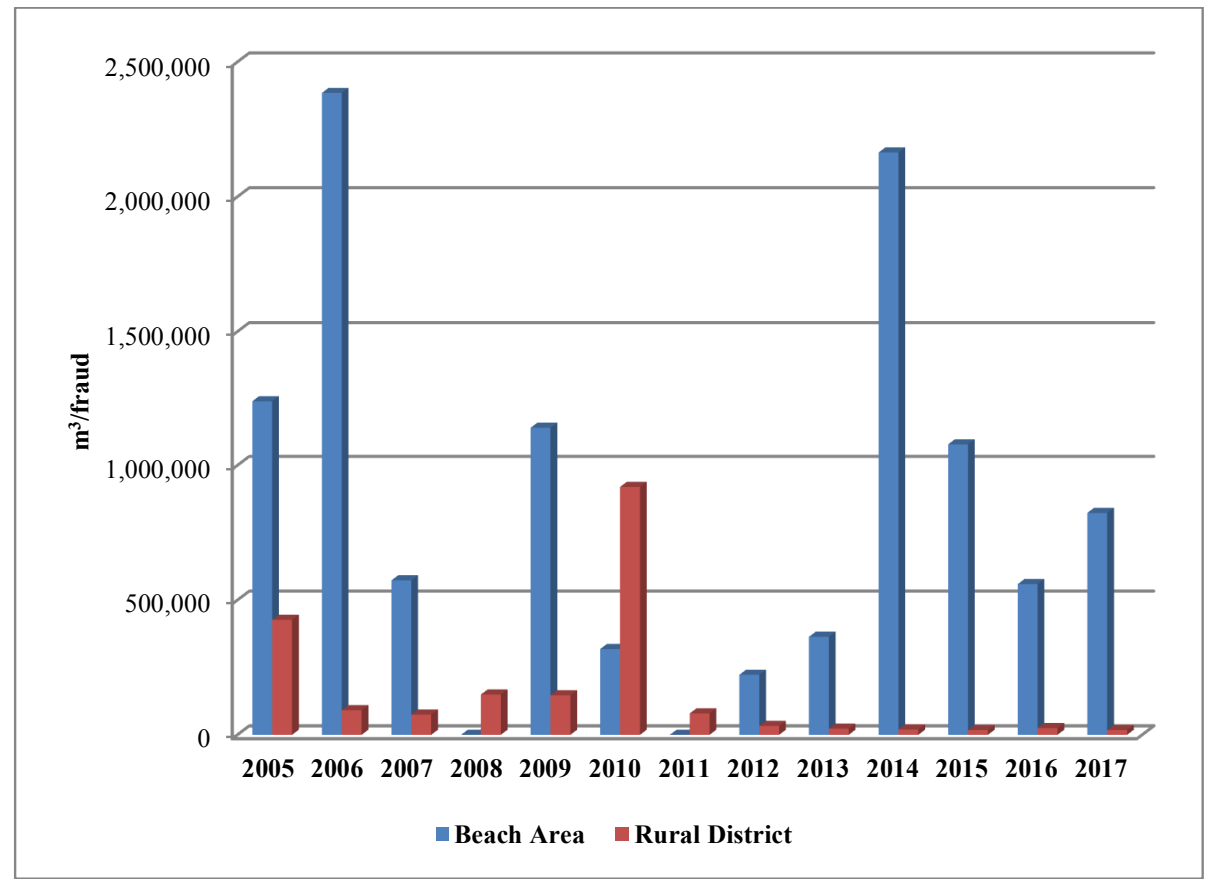

Figure 7. Evolution of the ratio water supply $\left(\mathrm{m}^{3}\right) /$ frauds detected in the low density urban model (2005-2017). Source: AMAEM. Own elaboration. In 2008 and 2011 AMAEM did not detected unauthorised consumption in the Beach Area.

The current period of reduction of precipitation (2014-2018) which affects this region has also influenced the trend for fraud. Unlike that which occurred with the factors with an economic component (income and effect of the crisis) this is the factor that explains the increase in unauthorised consumption in the detached house typology and its continuance to date. The year in which the greatest number of unauthorised consumption was recorded in this type, 2014, coincides with the driest year since 2000 (only $140 \mathrm{~mm}$ ). This relationship would be corroborated by a second element 
which is the marked concentration in the summer months, when $70 \%$ of the frauds of the whole year in the detached house type are committed (Figure 8). The factor that explains the seasonal concentration of the unauthorised consumption in the summer months would be the lack of precipitations in these months, the need to watering the gardens and to fill the swimming pool of these properties. Therefore, the summer dryness characteristic of the Mediterranean climate is accentuated by the current drought.

As occurred with the compact typology, one of the two areas (Rural District) concentrates a high number of unauthorised consumption. Together with the factor indicated (higher consumption and impact of the drought) it is necessary to incorporate new elements that explain the different behaviour in the low-density typology. This duality is related to the availability of alternative water resources other than drinking water. The Beach Area is the only sector of the municipality where, since 2003, AMAEM has been supplying properties with reused treated water for watering gardens of the detached houses. This is a factor that was not contemplated in the initial hypothesis, neither was it mentioned in the interviews held with the technicians of AMAEM. However, it bears a direct influence as a "unauthorised consumption dissuasion" factor since it represents the availability of a resource, the use of which is encouraged by its price, almost seven times cheaper than drinking water $\left(€ 0.32 / \mathrm{m}^{3}\right.$ compared to $€ 2.23 / \mathrm{m}^{3}$ ).

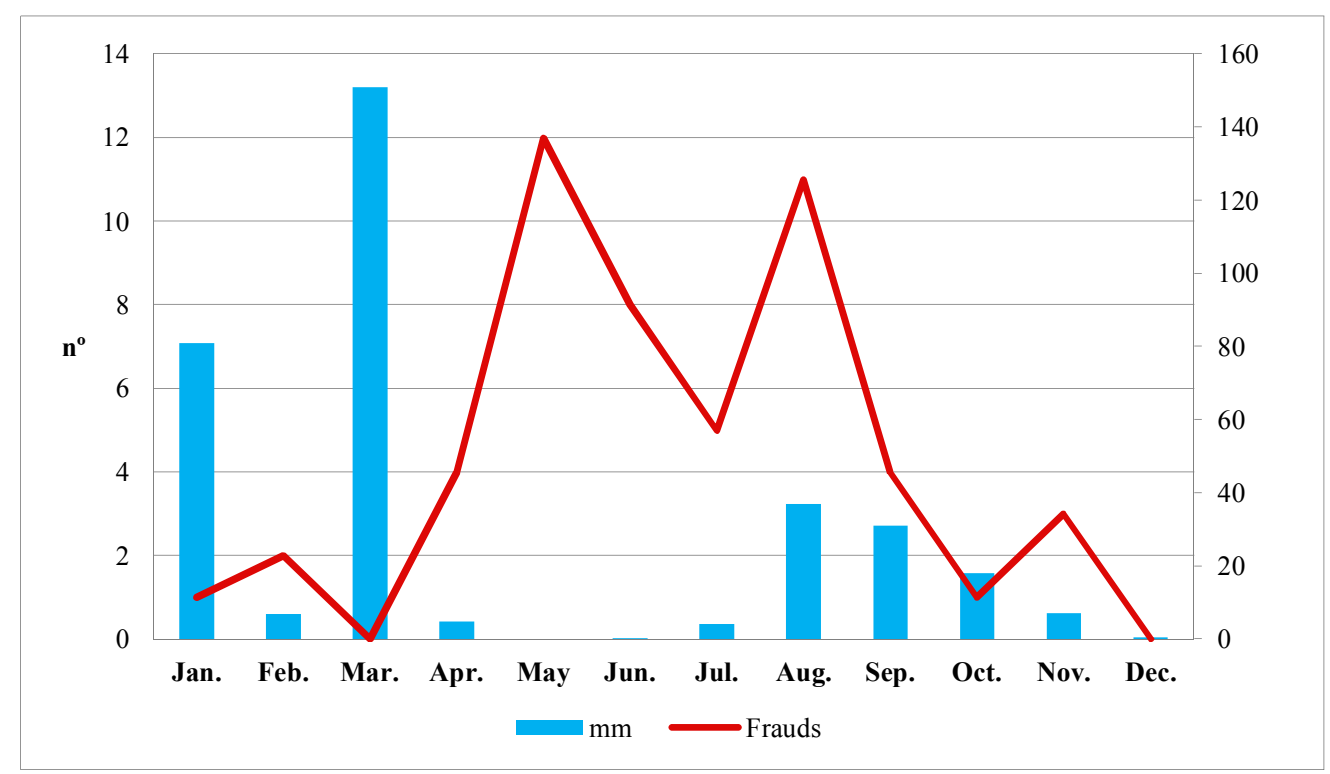

Figure 8. Evolution of unauthorised domestic water consumption detected in the low density urban model and monthly precipitations in the city of Alicante (2017). Source: AMAEM; AEMET (2017). Own elaboration.

The last factor to be considered is the improvement of the technology for the detection of unauthorised consumption. In 2011, a new plan for remote reading was launched with the following issues: (a) To avoid the nuisance of entering into private households to read meters; (b) To eliminate the estimation of consumption when customers were absent; (c) The access to in-depth and location-specific detailed knowledge of water use at the household scale for identifying patterns of consumption according to different variables; (d) The possibilities for segmenting users and developing new pricing schemes that capture the oscillations of water use throughout the day and the week; (e) The potential to engage users in more responsible behaviours; (f) To anticipate possible situations of leaks and other anomalies in the provision of the service; and (g) The immediate detection of anomalous (unauthorized consumption) and excessive consumption. The plan is to be fully operational in 2022 when all meters in Alicante (approximately 200,000) will be equipped with remote reading devices. For example, in 2011 only new 1165 smart meters were installed ( $0.60 \%$ of the total meters of the city), in 2014 this 
number amounts to $57,658(29 \%)$ and in 2017, 113,615 (56\%). It is important to note that the installation of the smart meters, in general, nowadays is only installed in the urban compact model.

As has already been stated, a considerable increase in unauthorised consumption is detected as of 2011 and this cannot be explained by the economic crisis alone. In this respect, it was in 2011 when AMAEM implemented a programme of measures and increased the intensity of surveillance for unauthorised consumption detection (hiring of personnel to increase monitoring of the condition of water meters in situ) and the implementation of the Remote Meter Reading Plan. With these new devices, technicians can detect any anomaly (leak, fault or unauthorised consumption) practically in real time, from the control room of AMAEM and this can be followed up by an inspection in situ by the technicians. The rise in the figures does not mean, therefore, that more frauds occurred as of 2011 but that more are now recorded and that, moreover, the implementation of this technology (Remote Reading) acts as a "unauthorised consumption dissuasion" factor in the guise of a big brother that controls consumption and enables the company to detect any anomaly (whether leaks or frauds) almost instantly. This is one of the main reasons that in the urban compact model, the trend of the unauthorised consumption has fallen since 2014.

According to the information provided by the technicians of AMAEM, rogues have always existed and the virulence of the crisis in its worst years led to water fraud being multiplied by five (2009-2013), reaching $400,000 \mathrm{~m}^{3} /$ year and a value of $€ 900,000$ per annum in the whole area served by AMAEM. In 2017, AMAEM has estimated that fraud amounted to around $120,000 \mathrm{~m}^{3}$ (some $€ 267,600$ ) which represents a reduction of $80 \%$ compared to 2013. If the amount of the unauthorised consumption is analysed per urban development type, in the low-density model AMAEM has estimated that detached houses obtained illegally an average of $€ 2007$ by fraud $\left(900 \mathrm{~m}^{3}\right)$ which represents a total of $€ 102,357$ and $45,900 \mathrm{~m}^{3}$ ( $38.25 \%$ of the total fraud volume of the city). The greatest volume obtained illegally overall in the city is recorded in the compact model $\left(74,900 \mathrm{~m}^{3}\right.$ and a total of $\left.€ 165,243\right)$. However, the mean amount obtained illegally per fraud in this typology decreases compared to low density development ( $€ 856$ and $383 \mathrm{~m}^{3}$ ), in view of the lower average consumption per bill.

\section{Discussion}

In this study, it has been possible to ascertain the evolution of unauthorized water consumption, their causes and their distribution according to geographic area and urban development type in the city of Alicante. With regard to the determining factors that may have influenced the increase in unauthorized consumption, a multiple and interrelated amalgam has been identified. One of the aspects that has had a direct impact has been the economic crisis (2008) which has aggravated even more the socio-economic situation of the most vulnerable classes. This matter has been accentuated by the increase of $92.79 \%$ in the price of water in the last decade in the city of Alicante. This fact has been apparent in the neighbourhoods of the North District of the city (115 contracts/fraud in 2017). In the 2005-2017 period, with a total population of $13.38 \%$, it concentrated $59 \%$ of the frauds of the whole city. Unauthorised water consumption, as in other basic services, has been considered an indicator that is able to measure the socio-economic level of certain neighbourhoods of a city [23]. This is due to the decision of the residents to adopt illegal measures to obtain access to a basic resource such as water in view of the impossibility of paying the expense deriving from its use.

When the subject of unauthorised water consumption is raised, it is thought that this occurs generally in neighbourhoods with low income levels. However, it also takes place in sectors with high income levels. In the latter, the reasons are not related to the difficulty in accessing to water but to the reduction of the total amount of the bill associated with high consumption [33,42]. In this respect, it is appropriate to indicate that a high percentage of the frauds in economic terms (not in the number of incidents) has been detected in the sectors where the social classes with the greatest purchasing power reside (the average amount obtained illegally per detached house is $€ 2007$ ). $19.23 \%$ of total fraud is recorded in the low density urban development model (Beach Area and Rural District). However, in this area the economic crisis may have had an impact, too. In this case, it would be the 
need to reduce the water bill owing to the high levels of water consumption generated by outdoor uses. And this factor has been accentuated by the increase in the price of water and the current period of drought which has increased the need to water gardens and, consequently, the need to reduce the volume of water consumed. In this respect, Morote et al. [25] calculated for the city of Alicante that the average daily consumption per household in the urban core (properties without garden or swimming pool) amounted to 244 L compared to 1052 L/property/day for detached houses. As Hurd [43] shows, consumption for outdoor uses may represent more than $50 \%$ of the total domestic water expense in Australia. All in all, taking into account the semi-arid area where it is place Alicante (southern of Spain; $311 \mathrm{~mm} /$ year).

The price paid for water becomes a fundamental element to explain the rising trend for fraud. And this relevance is accentuated by the interaction with the economic crisis, which has led to a decrease in income, especially in the middle and lower classes. The impact of water policy changes in relation to the Dublin Principles (1992) that consider water as an economic value along with the Water Framework Directive (2000/60/EC) affected regulations and tariffs. The increase in water prices is a factor to highlight [44]. The evolution of prices paid for water is complex given the different aspects covered by the overall water bill (consumption fee, sewage treatment and network tax). An analysis of each of the aspects covered by the water bill points to a different tendency. In relation to water, the recorded rises do not reflect a linear increase but instead, they are related to significant diversities according to the consumption blocks. The price paid per cubic metre in the first threshold (up to $9 \mathrm{~m}^{3}$ per quarter) has not risen since 2007. In contrast to this, the increase in the other blocks is progressive (between 23\% and 45\%). The increase observed in the last block clearly reflects the desire to deter and control consumption by owners of houses with outdoor uses. The price increase associated with the Government of Valencia's sewage treatment tax should also be mentioned. For a bill of $30 \mathrm{~m}^{3}$, this has resulted in an increase of $36.98 \%$ in service charges and $35.07 \%$ in consumption charges over the last ten years. Similarly, VAT charges have augmented by $26.02 \%$ for the same bill during the same period [25]. This increase may have contributed towards shrinking consumption levels. On the other hand, if the evolution of the Consumer Price Index and the family's income are compared, it can be concluded that families have lost their purchasing power in relation to the increase of water prices. In this sense, according to the data provided by the INE [45], the CPI of the province of Alicante between 2007 and 2013 increased by 15.3\% but the income of families was reduced by 10.13\% (25,802 in 2007 and 23,189 in 2013 in the Region of Valencia) [46].

For the case of the low density urban development typology, a determining factor has been the availability of a cheaper resource. In this case, Alicante is one of the few Spanish cities that has been supplying regenerated treated water in the Beach Area since 2003 for the watering of private gardens. For example, the total supplied has risen from $43,668 \mathrm{~m}^{3}$ in 2003 to 481,654 in 2017 (57\% of the treated water supplied in the city). Furthermore, it should be stated that the availability of this resource not only means that users do not need to obtain water illegally in order to reduce the final amount of their bill but it has also had a repercussion in that the consumption of drinking water in these households has been reduced by 54\% between 2007 and 2013 since drinking water has been replaced by treated water [25].

Another key factor in the recording of frauds has been the improvement in technology for their detection and for better control and management of user consumption and leak detection. In the detection of unauthorised consumption, new water meters with remote reading in Alicante may enable the detection in almost real time of any leak or breakdown of the system, as well as the exact location of distress in the network, as other studies have already documented [10]. These remote meter-reading schemes have helped, according to company sources, to "reduce the average time of a water leakage," both at the final point of consumption (customer) and at the network level. This technology also helps to detect cases of anomalous or excessive consumption. On the other hand, the company suggests that with this new system, between 120,000 and 140,000 $\mathrm{m}^{3}$ /year corresponding to fraudulent readings could be detected [26]. 
Smart or intelligent metering first and foremost enhances the understanding of "when," "where" and "how" water is used [29]. Debates on the potential of smart meters can be traced back to as early as the 1980s and 1990s. However, it was in the 2000s when this technology gained attention, especially in energy and, later, in urban water management [26]. According to Boyle et al. [29], the desire to increase data regarding end-use and time of use of household water and the quest for reducing the (labour) costs for meter reading are two critical drivers that guide the implementation of smart metering schemes. The smart city is a powerful concept that has captured the attention of urban policy makers, corporations and international institutions, as it promises a new era of optimized infrastructure management that connects objects, organizations and citizens in new ways [47].

Losses can occur at all points in a supply system, from capture to land connections. For example, in Brazil, the loss rate in the water supply system is around 40\% [48]. In Gaza, Hummaid and Barhoum [35] explain that it is clearly very important to use intelligent data mining methods in unauthorised consumption detection, such as rule induction. One of the most relevant points of their work is the financial loss with each detected unauthorised consumption. Another important point is the detection of non-technical losses caused by water meter tampering, meter malfunction and billing irregularities. They concluded that the study may provide more realistic results, so the aim is to build a new historical consumption dataset to represent customers' consumption profiles individually to take advantage of classification, in order to predict fraudulent customer consumption after determining the suspicious area. Obradović [49] proposed in Herzegovina (Bosnia and Herzegovina) the utilization of remote systems to increase control in the distribution network and to model the behaviour of the network from the viewpoint of demand and losses; thus, the author used pressure and flow sensors. Gouthaman et al. [16] proposed an application for unauthorised consumption detection in water distribution based on a Supervisory Control and Data Acquisition (SCADA), which uses a data-driven Decision Support System (DSS), applying a water flow active control in the water distribution network.

The relationship between the adoption of these technological systems and the decrease in unauthorised consumption has also been ascertained in other parts of Spain. In the city of León (northern Spain), the number of frauds recorded increased more than six-fold between 2011 and 2013, from 19 to 155 infractions, respectively. This increase was related to the economic crisis but was also due to the intensification of the inspection tasks by the company responsible for water supply. The increased control made it possible to bill more than 74,000 $\mathrm{m}^{3}$ /year and an estimated amount of $€ 52,490$ [50]. In Seville (southern Spain), the research group "Tecnología Electrónica e Informática Industrial" has developed the project "Detection of hidden consumption to reduce water not billed owing to non-technical losses" the aim of which is to discover frauds in the water supply network. By combining statistics with artificial intelligence large volumes of data are processed and an advanced analysis is obtained that detects anomalies in water consumption. They detected between $3 \%$ and $6 \%$ of customers who made inappropriate use of the water supply in 2014. Furthermore, the highest levels of fraud were detected in supplies to houses (domestic consumption) and industrial estates (large consumers). In the same city, the company that manages water supply (Empresa Metropolitana de Abastecimiento y Saneamiento de Aguas de Sevilla, Emasesa) has noticed a decrease of $28 \%$ in the number of frauds between 2013 and 2016. The greatest number of incidents was recorded in 2013 (coinciding with the greatest intensity of the economic crisis), when 1,394 cases were detected. Prior to 2013, an average of 760 incidents occurred per year. Since this maximum value, the trend has been a decrease to 1004 in 2016. The most frequent frauds are illegal connections and meter tampering and, in relationship with distribution, $75 \%$ correspond to domestic users and the rest to commercial and industrial users [11].

Some of the conclusions reached in the study by Monedero et al. [10] were: (1) The fraud leaves no sign of manipulation, making it quite difficult to detect frauds via inspection. During the day, fraudulent customers usually remain vigilant because an inspector can detect fraud by surprise; (2) Having a higher frequency of reading values (currently, four per year) significantly improves the results. This is due to the fact that sometimes the effect of this manipulation is imperceptible in water meters read quarterly in which detecting drops in consumption is not possible; and (3) The main 
solution to improve the results is the installation of smart meters. However, attending the technicians of AMAEM comments', the installation of new smart meters is also affected with new types of fraud that not all people know.

\section{Conclusions}

The analysis of unauthorised water consumption offers interesting information regarding the current status and characteristics of the management and control of water consumption in a city. However, it is a subject that has rarely been considered in socio-regional studies since it has traditionally been analysed from a strictly economic or technical perspective $[10,11,13,32,34-36]$, This study aims to contribute a socio-economic and regional view to the international and national (Spain) scientific literature analysing the causes that explain unauthorised domestic water consumption, since it is one of the few studies carried out on this topic and the first in the area under study (city of Alicante). Besides, with this study some factors could be taking into account in other cities for improve the management and the reduction of the unauthorised consumption such as the use of treated water and the implementation of the technology (smart meters).

In the detached housing development type, it has been ascertained, moreover, that the use of unconventional water resources (reuse of treated water) acts as a factor to reduce unauthorised consumption since users have access to a resource that is up to seven times cheaper than drinking water and, therefore, despite the fact that water expenditure is high in these households, with this resource it is possible to reduce the final amount paid in the water bill. Therefore, this is a "dissuasive" factor that should be considered seriously in future due to the potential it offers to supply certain urban uses. Another key factor in the study of unauthorised water consumption has been the development and implementation of technology for its detection and, in the case of the city of Alicante, this has been the implementation of the Remote Reading Plan in 2011. It has been seen how, since 2011, detection of unauthorised consumption has increased and this is not because more frauds are committed but because this technology enables greater control of the knowledge, almost in real time, of any incident affecting the water supplied to the city.

In the city of Alicante, the urban area with the highest ratio of contracts/fraud is the North District (115 contracts per fraud). However, one of the conclusions reached for the case of this city of is that, "unauthorised consumption is committed by all social classes," from those with the least purchasing power to the most well-off classes. And it can be underlined that it is in the properties of the detached houses where the volume of water and the amount of fraud per household are highest owing to the high levels of consumption generated by the watering of gardens and filling of swimming pools. Added to this is the increase in the price of water and a greater need for water owing to the current drought suffered in the south-east Spain. In the North District, it should be pointed out that the number of unauthorised consumption has been reduced by $50 \%$, perhaps owing to the monitoring work of AMAEM, the control offered by remote meter reading, or because actions such as the income-based discount adopted by the water supply company have meant that families at risk of social vulnerability do not need to commit unauthorised consumption. However, this is not the case in the low density urban development type in which the number of unauthorised consumption remains constant and this is due, to a large extent, to the effects of the current drought 2014-2018 which has increased the need for watering and water consumption for outdoor uses and which increases considerably in the summer months.

Furthermore, it is relevant to insist that, in the words of the technicians of AMAEM, "in the majority of cases, when unauthorised consumption take place, more water is lost than that which is really obtained illegally." Therefore, it is appropriate to ask whether it is worthwhile for companies to invest in technology and employees for surveillance work to perform better water management, if there is a lack of awareness in society.

Finally, all of these arguments should be considered in conjunction with the need for better management and control of water consumption. In words of Pietrucha-Urbanik and Tchórzewska-Cieślak [22] a detailed 
analysis of the failure and the water loss of the water supply network should be the main element of the urban management water supply network, particularly in the strategic plans for its modernization. According to Lambert [7], as natural water resources become scarcer, higher values will be placed upon source waters, leading inevitably to greater investment in management of water losses. In the case of Alicante, AMAEM has been done a big effort to improve water management and the reduce of the water supply in the last years. This reduction obeying multiple interrelated causes, such as more efficient water network, growing consumer awareness and also the effects of rising prices and taxes $[25,26]$. All in all, the improve of the water management become more important, especially taking into account the future climate change scenarios that, in the Mediterranean region, forecast a reduction in days of precipitation, greater intensity of precipitations, longer duration of droughts and, according to the water management plans, greater pressure on water resources owing to the increase in demand.

Author Contributions: The two authors wrote the paper.

Funding: The results presented in this article are part of the research project "Uses and management of non-conventional water resources on the coast of Valencia and Murcia as an adaptation strategy to drought" funded by the Spanish MINECO under grant number CSO2015-65182-C2-2-P.

Acknowledgments: The authors would like to express their cordial thanks to Aguas Municipalizadas de Alicante, Empresa Mixta for providing the data on water consumption and especially Asunción Martínez, Francisco Bartual, Francisco Agulló, César Vázquez, Vicent Martínez and Antonio Sánchez.

Conflicts of Interest: The authors declare no conflict of interest.

\section{References}

1. Lambert, A.; Brown, T.G.; Takizawa, M.; Weimer, D. A Review of Performance Indicators for Real Losses from Water Supply Systems. AQUA 1999, 48, 227-237. [CrossRef]

2. Lambert, A.; Hirner, W. Losses from Water Supply Systems: Standard Terminology and Recommended Performance Measures. IWA Website, 2000. Available online: www.iwahq.org.uk/bluepages (accessed on 1 June 2018).

3. Al-Washali, T.; Sharma, S.; Kennedy, M. Methods of Assessment of Water Losses in Water Supply Systems: A Review. Water Resour. Manag. 2016, 30, 4985-5001. [CrossRef]

4. Farley, M.; Wyeth, G.; Ghazali, Z.; Istandar, A.; Singh, S. The Manager's Non-Revenue Water Handbook: A Guide to Understanding Water Losses; United States Agency for International Developing and Ranhill Utilities Berhad: Bangkok, Thailand; Kuala Lumpur, Malaysia, 2008.

5. Alegre, H.; Hirner, W.; Baptista, J.M.; Parena, R. Performance Indicators for Water Supply Services; IWA Manual of Best Practice; IWA: London, UK, 2000.

6. Wu, Z.Y.; Farley, M.; Turtle, D.; Kapelan, Z.; Boxall, J.; Mounce, S.; Dahasahasra, S.; Mulay, M.; Kleiner, Y. Water Loss Reduction, 1st ed.; Bentley Institute Press: Exton, PA, USA, 2011.

7. Lambert, A. International Report on Water Losses Management and Techniques: Report to IWA Berlin Congress, October 2001. Water Sci. Technol. Water Supply 2001, 2, 1-22. [CrossRef]

8. Brothers, K.J. A practical approach to Water Loss Reduction. Water 2003, 21, 54-55.

9. Shubo, T. Sustentabilidade do Abastecimento e da Qualidade da Água Potável Urbana; Escola Nacional de Saúde Pública; Fund. Oswaldo Cruz: Rio de Janeiro, Brazil, 2003.

10. Monedero, I.; Biscarri, F.; Guerrero, J.I.; Roldán, M.; León, C. An Approach to Detection of Tampering in Water Meters. Procedia Comput. Sci. 2015, 60, 413-421. [CrossRef]

11. Monedero, I.; Biscarri, F.; Guerrero, J.I.; Peña, M.; Roldán, M.; León, C. Detection of Water Meter UnderRegistration Using Statistical Algorithms. J. Water Resour. Plan. Manag. 2015, 142. [CrossRef]

12. American Water Works Association. Manual of Water Supply Practices. In Water Audits and Leak Detection, 2nd ed.; American Water Works Association: Denver, CO, USA, 1999; Volume 36.

13. De Castro Fettermann, D.; Guerra, K.C.; Mano, A.P.; De Almeida Marodin, G. A method for fraud detection in water supply system. Interciencia 2015, 40, 114-120.

14. Solanas, J.L.; Cussó, M.R. MCP methodology for intelligent water metering (IWM): Assessment of low flow consumption. Water Sci. Technol. Water Supply 2012, 12, 270. [CrossRef] 
15. Solanas, J.L.; Cussó, M.R. Multivariate consumption profiling (MCP) for intelligent meter systems: A methodology to define categories and levels. Water Sci. Technol. Water Supply 2010, 10, 710. [CrossRef]

16. Gouthaman, J.; Bharathwajanprabhu, R.; Srikanth, A. Automated urban drinking water supply control and water theft identification system. In Proceedings of the IEEE Students' Technology Symposium, Kharagpur, India, 14-16 January 2011; pp. 87-91.

17. Aksela, K.; Aksela, M. Demand estimation with automated meter reading in a distribution network. J. Water Resour. Plan. Manag. 2011, 137, 456-467. [CrossRef]

18. McKenna, S.A.; Fusco, F.; Eck, B.J. Water Demand Pattern Classification from Smart Meter Data. Procedia Eng. 2014, 70, 1121-1130. [CrossRef]

19. Pietrucha-Urbanik, K. Multidimensional comparative analysis of water infrastructures differentiation. Environ. Eng. 2013, IV, 29-34.

20. Tchorzewska-Cieslak, B.; Rak, J. Method of identification of operational states of water supply system. Environ. Eng. 2009, III, 521-526.

21. Pietrucha-Urbanik, K.; Tchorzewska-Cieslak, B. Water Supply System operation regarding consumer safety using Kohonen neural network. In Proceedings of the 22nd Annual Conference on European Safety and Reliability, Amsterdam, The Netherlands, 29 September-2 October 2013; pp. 1115-1120.

22. Pietrucha-Urbanik, K.; Tchórzewska-Cieślak, B. Research methodology of water network failure in terms of reneval. J. KONBiN 2015, 1, 233-242.

23. Detroz, J.P.; Da Silva, A.T. Fraud detection in water meters using pattern recognition techniques. In Proceedings of the ACM Symposium on Applied Computing, Marrakech, Morocco, 3-7 April 2017; pp. 77-82.

24. Gil, A.; Hernández, M.; Morote, A.F.; Rico, A.M.; Saurí, D.; March, H. Tendencias del Consumo de Agua Potable en la Ciudad de Alicante y Área Metropolitana de Barcelona, 2007-2013; Universidad de Alicante: Alicante, Spain, 2015.

25. Morote, A.F.; Hernández, M.; Rico, A.M. Causes of Domestic Water Consumption Trends in the City of Alicante: Exploring the Links between the Housing Bubble, the Types of Housing and the Socio-Economic Factors. Water 2016, 8, 374. [CrossRef]

26. March, H.; Morote, A.F.; Rico, A.M.; Saurí, D. Household smart metering in Spain: Insights from the experience of remote meter reading in Alicante. Sustainability 2017, 9, 582. [CrossRef]

27. Morote Seguido, A.F.; Rico Amorós, A.M. La telelectura como tecnología resiliente frente al cambio climático. La experiencia del control inteligente del agua en la ciudad de Alicante; Allende Álvarez, F., Cañada Torrecilla, R., Fernández Mayoralas, G., Gómez Mediavilla, G., López Estébanez, N., Palacios García, A., Rojo Pérez, F., Vidal Domínguez, M.J., Eds.; Universidad Autónoma de Madrid: Madrid, Spain, 2017; pp. 739-748.

28. Beal, C.D.; Stewart, R.A.; Fielding, K. A novel mixed method smart metering approach to reconciling differences between perceived and actual residential end use water consumption. J. Clean. Prod. 2013, 60, 116-128. [CrossRef]

29. Boyle, T.; Giurco, D.; Mukheibir, P.; Liu, A.; Moy, C.; White, S.; Stewart, R. Intelligent Metering for Urban Water: A Review. Water 2013, 5, 1052-1081. [CrossRef]

30. Cole, G.; Stewart, R. Smart meter enabled disaggregation of urban peak water demand: Precursor to effective urban water planning. Urban Water J. 2013, 10, 174-194. [CrossRef]

31. March, H.; Ribera-Fumaz, R. Smart constradictions: The politics of making Barcelona a self-sufficient city. Eur. Urban Reg. Stud. 2016, 1-15. [CrossRef]

32. Garcia, D.; Puig, V.; Quevedo, J.; Cugueró, M.A. Big data analytics and knowledge discovery applied to automatic meter readers. In Real-time Monitoring and Operational Control of Drinking-Water Systems; Springer: Cham, Aargau, Switzerland, 2017; pp. 401-423.

33. Morote, A.F.; Saurí, D.; Hernández, M. Residential Tourism, Swimming Pools and Water Demand in the Western Mediterranean. Prof. Geogr. 2017, 69, 1-11. [CrossRef]

34. Candelieri, A. Clustering and support vector regression for water demand forecasting and anomaly detection. Water 2017, 9, 224. [CrossRef]

35. Humaid, E.H.; Barhoum, T. Water consumption financial fraud detection: A model based on rule induction. In Proceedings of the 2013 Palestinian International Conference on Information and Communication Technology, Gaz, Palestin, 15-16 April 2013; pp. 115-120.

36. McCann, B. Campaigning to combat water sector corruption. Water 2006, 21, 13-14. 
37. Swyngedouw, E. Into the Sea: Desalination as Hydro-Social Fix in Spain. Annu. Assoc. Am. Geogr. 2013, 103, 261-270. [CrossRef]

38. Morote, A.F.; Olcina, J.; Rico, A.M. Challenges and Proposals for Socio-Ecological Sustainability of the Tagus-Segura Aqueduct (Spain) under Climate Change. Sustainability 2017, 9, 2058. [CrossRef]

39. Gil, A.; Rico, A.M. El Problema del Agua en la Comunidad Valenciana; Fundación de la Comunidad Valenciana Agua y Progreso: Valencia, Spain, 2007.

40. Rico, A.M.; Olcina, J.; Saurí, D. Tourist land use patterns and water demand: Evidence from the Western Mediterranean. Land Use Policy 2009, 26, 493-501. [CrossRef]

41. Centro de Investigación y Desarrollo Estratégico, CIDES. Encuesta de Condiciones de Vida y Situación Laboral en la Ciudad de Alicante. 2016. Available online: www.alicante.es/sites/default/files/documentos/ documentos/encuesta-condiciones-vida-y-situacion-laboral-ciudad-alicante-diciembre-2016/informeexclusion-social.pdf (accessed on 5 April 2018).

42. Morote-Seguido, A.F.; Hernández-Hernández, M. Green areas and water management in residential developments in the European Western Mediterranean. A case study of Alicante, Spain. Dan. J. Geogr. 2016, 116, 190-201. [CrossRef]

43. Hurd, B.H. Water conservation and residential landscape: Household preferences, household choices. J. Agric. Resour. Econ. 2006, 31, 21-32.

44. Dalhuisen, J.; Florax, R.; De Groot, H.; Nijkamp, P. Price and Income Elasticities of Residential Water Demand: A Meta-Analysis. Land Econ. 2003, 79, 292-308. [CrossRef]

45. Instituto Nacional de Estadística. Cálculo de Variaciones del Índice de Precios de Consumo. 2016. Available online: http:/ / www.ine.es/varipc/verVariaciones.do;jsessionid=AEBB85F409D6D6A8CEC5DD159E864830. varipc01?idmesini=1\&anyoini=2007\&idmesfin=12\&anyofin=2013\&ntipo=3\&enviar=Calcular (accessed on 15 May 2018).

46. Instituto Nacional de Estadística. Renta por Hogar por Comunidades Autónomas. 2016. Available online: http:/ / www.ine.es/jaxiT3/Datos.htm?t=9949 (accessed on 15 May 2018).

47. Taylor Buck, N.; While, A. Competitive urbanism and the limits to Smart City innovation: The UK Future Cities initiative. Urban Stud. 2015, 54, 501-519. [CrossRef]

48. SNIS. Diagnóstico dos Serviços de Água e Esgotos-2010. Sistema Nacional de Informações sobre Saneamento: Brazil, 2010. Available online: www.snis.gov.br/Arquivos_SNIS/5_DIAGNOSTICOS/5.1_Agua\&Esgotos/5. 1.16_Diagnostico2010/Planilhas/Planilhas_AE2010_Resumo.zip (accessed on 10 June 2013).

49. Obradović, D. Modelling of demand and losses in real-life water distribution systems. Urban Water 2000, 2, 131-139. [CrossRef]

50. Caballero, A. Los Fraudes Ilegales por Fraude se Multiplican en seis Años. Diario de León. Available online: http:/ / www.diariodeleon.es/noticias/leon/fraudes-enganches-ilegales-agua-multiplican-seis-ano_ 852465.html (accessed on 4 January 2018).

(C) 2018 by the authors. Licensee MDPI, Basel, Switzerland. This article is an open access article distributed under the terms and conditions of the Creative Commons Attribution (CC BY) license (http:/ / creativecommons.org/licenses/by/4.0/). 